\title{
Effect of RVC porosity on the performance of $\mathrm{PbO}_{2}$ composite
}

4 coatings with titanate nanotubes for the electrochemical oxidation

\section{of azo dyes}

G. Ramírez ${ }^{1}$, F. J. Recio ${ }^{2,3, \#, ~ P . ~ H e r r a s t i ~}{ }^{1, \#}$, C. Ponce-de-León ${ }^{4, \#}$, I. Sirés ${ }^{5, *, \#}$

${ }^{1}$ Universidad Autónoma de Madrid, Facultad de Ciencias, Departamento de Química Física Aplicada, 28049 Cantoblanco, Madrid, Spain

${ }^{2}$ Facultad de Química, Departamento de Química Inorgánica, Pontificia Universidad Católica de Chile. Av. Vicuña Mackenna 4860, Macul, Santiago de Chile 9170022, Chile Católica de Chile. Av. Vicuña Mackenna 4860, Macul, Santiago de Chile, Chile Faculty of Engineering and the Environment, University of Southampton, Highfield, Southampton, SO17 1BJ, United Kingdom

${ }^{5}$ Laboratori d'Electroquímica dels Materials i del Medi Ambient, Departament de Química Física, Facultat de Química, Universitat de Barcelona, Martí i Franquès 1-11, 08028 
Reticulated vitreous carbon (RVC) of different porosities $(20,45,60,80$, and 100 ppi-

3 pores per inch) has been used as a large surface area substrate for preparing $3 \mathrm{D}-$ like $\mathrm{PbO}_{2}$ coatings $\left(\mathrm{RVC} / \mathrm{PbO}_{2}\right)$ as well as composite coatings with hydrothermally synthesized titanate nanotubes $\left(\mathrm{RVC} / \mathrm{PbO}_{2} / \mathrm{TiNT}\right)$ by galvanostatic electrodeposition from baths containing lead(II) methanesulfonate and methanesulfonic acid. The effect of the RVC porosity on the coating thickness, the electrocatalytic behaviour and the ability to remove the colour and total organic carbon (TOC) from solutions containing the azo dye Methyl Orange has been systematically assessed. As shown from scanning electron micrographs, the greatest thickness (up to $120 \mu \mathrm{m}$ ) was obtained using $>60 \mathrm{ppi}$, but the $\beta-\mathrm{PbO}_{2}$ nanocrystallytes mainly grew on 11 the external surface, leaving mostly uncoated inner RVC stripes and ending in planar-like $\mathrm{PbO}_{2}$-based electrodes. In contrast, thinner but perfectly adherent and homogeneous coating of the inner and outer surface was achieved with 20-60 ppi, showing electrodes with an optimal three-dimensionallity. This was especially confirmed by cyclic voltammograms for the composite coatings, as deduced from their highest electroactivity that can be related to enhanced adsorption onto the TiNT clusters and the larger ability to produce active $\mathrm{PbO}_{2}\left({ }^{\bullet} \mathrm{OH}\right)$. The comparative electro-oxidation of $0.25 \times 10^{-3} \mathrm{~mol} \mathrm{dm}^{-3}$ Methyl Orange acidic solutions in $0.05 \mathrm{~mol} \mathrm{dm}^{-3} \mathrm{Na}_{2} \mathrm{SO}_{4}$ at $0.6 \mathrm{~A}$ demonstrated that $\mathrm{RVC}$ (45 ppi)/ $\mathrm{PbO}_{2} / \mathrm{TiNT}$ was the optimum material. It allowed the quickest decolourisation, reaching $60 \%$ in $2.5 \mathrm{~min}$ and $>$ $98 \%$ at $45 \mathrm{~min}$, and $>55 \%$ TOC abatement at $240 \mathrm{~min}$. The anode presented a perfect surface coverage, with no evidence of RVC degradation. The effect of dye concentration and supporting electrolyte nature was studied, revealing a very positive effect of $\mathrm{NaCl}$.

Keywords: Electrochemical advanced oxidation processes; Lead dioxide anode; Methanesulfonic acid; Reticulated vitreous carbon; Water decontamination 


\section{Introduction}

In the last decade, water demand has increased due to its intensive use in different activities and, as a result, projection scenarios suggest that there will be an increasing number of water-deficit regions worldwide [1]. Therefore, great effort is needed for developing powerful water treatment technologies to allow reusing industrial water once the complete removal of hazardous polluants like heavy metals, dyes, pesticides and pharmaceuticals has been ensured [2]. There exists a large variety of physicochemical and biological processes for water decontamination, including electrochemical technologies that have been successfully tested for treating pesticides [3], pharmaceuticals [4] and synthetic dyes [5]. Among those organic chemicals, azo dyes are especially relevant because they are widely used in textile, food and paper and leather industries and produce odor, color and serious environmental and health issues [6]. These compounds contain one or more azo bonds $(-\mathrm{N}=\mathrm{N}-)$ as chromophore group linked to aromatic structures with functional groups such as $-\mathrm{OH}$ and $-\mathrm{SO}_{3} \mathrm{H}$, among others [5]. Many methods have been used to remove azo dyes from water, as for example adsorption [7], coagulation [8] and advanced oxidation processes (AOPs) like Fenton's reagent [9]. However, these processes are expensive, inefficient, present operational problems like complex setups or handling and, frequently, yield either scondary pollution or hazardous by-products that tend to accumulate in final solutions. Consequently, there has been increasing interest in the development of simpler and more efficient separation and degradation electrochemical technologies to address this problem.

Lately, it has been demonstrated that the electrochemical AOPs (EAOPs), whose oxidative ability is governed by hydroxyl radicals $\left({ }^{\circ} \mathrm{OH}\right)$, possess peerless ability for destroying azo dyes contained in water matrices [10]. In EAOPs, the destruction of the organic molecules is mediated by ${ }^{\bullet} \mathrm{OH}$ mainly formed from water electro-oxidation (EO) at 
1 the anode (M) via reaction (1) [11-20] or by means of the electrogenerated Fenton's reagent in 2 the bulk [17,19-23].

$$
\mathrm{M}+\mathrm{H}_{2} \mathrm{O} \rightarrow \mathrm{M}\left({ }^{\bullet} \mathrm{OH}\right)+\mathrm{H}^{+}+\mathrm{e}^{-}
$$

Among them, EO is the most widespread method because of its simplicity, adaptability and scale-up as compact modularized systems. At high applied current, the degradation of the organic molecules by adsorbed $\mathrm{M}\left({ }^{\bullet} \mathrm{OH}\right)$ prevails over their direct oxidation at $\mathrm{M}[12,24,25]$. Dimensionally-stable anodes and Pt favour the conversion of the initial pollutant to stable intermediates, whereas high oxidation power anodes like boron-doped diamond (BDD) and $\mathrm{PbO}_{2}$ promote the total mineralization of solutions because the $\mathrm{M}\left({ }^{\bullet} \mathrm{OH}\right)$ are physisorbed [26].

Despite the lower degradation kinetics achieved with $\mathrm{PbO}_{2}$ compared to $\mathrm{BDD}$ [27], it has 11 been employed by many authors because it is less expensive, presents a high stability in a wide range of electrolytes and can be readily prepared by electrodeposition [28]. EO with $\mathrm{PbO}_{2}$ anodes has been proven an effective technology for the degradation of azo dyes like Methyl Red [11], Methyl Orange [29], Reactive Blue 194 [30] and Reactive Red 195 [31]. Traditionally, the $\mathrm{PbO}_{2}$ coatings have been synthesized by anodic deposition onto planar substrates, being $\mathrm{Ti}$ the preferred material [29-33]. Regarding the electrolyte for performing the electrodeposition, oxidising and toxic acidic media such as $\mathrm{HClO}_{4}, \mathrm{HNO}_{3}$ and $\mathrm{H}_{2} \mathrm{SO}_{4}$ are usually employed but, in recent years, methanesulfonic acid (MSA) has arisen as a more environmentally friendly medium. MSA yields a higher deposition rate of $\beta-\mathrm{PbO}_{2}$ [34,35], which is the most suitable allotrope for organics oxidation owing to its open structure that provides a larger active surface area [36,37]. Despite the good results obtained in EO with planar anodes, the potential benefits of using materials with a larger surface-to-volume ratio are undeniable since a clear mass transport enhancement is expected, which therefore counteracts the limitations of the low space-time yield and normalized space velocity [38]. As 
1 significantly improved [39,40]. For example, BDD meshes with a continuous honeycomb

2 structure have been used for the electro-oxidation of Indigo dye [41], whereas perforated

3 metal plates, metal foams or DSA meshes are also available in the market. Conversely, the

4 use of cheaper, raw carbonaceous materials as the anode in EO becomes severely restricted

5 due to their low ability to generate ${ }^{\bullet} \mathrm{OH}$ and, more importantly, their poor mechanical

6 stability, which limits their applicability to 3D electrochemical reactors equipped with packed

7 beds of discrete bipolar particles [42]. Worth highlighting, 3D-like anodes composed of thin

8 active layers of metal or metal oxide coatings onto continuous porous carbonaceous matrices

9 seems rather advantageous, since the amount of catalytic material to produce ${ }^{\bullet} \mathrm{OH}$ can be kept

to a minimum by controlling the electrodeposition parameters. Liu et al. [43] prepared Bi-

11 doped $\mathrm{SnO}_{2}$-coated carbon nanotubes for $\mathrm{EO}$ of organics, whereas some of us recently reported the manufacture of $\mathrm{PbO}_{2}$ anodes on reticulated vitreous carbon (RVC) with a fixed porosity [44]. As far as we know, that paper and a recent one by Chai et al. [45] are the sole studies on electrodeposited 3D-like $\mathrm{PbO}_{2}$ anodes for $\mathrm{EO}$ of organics.

As a step further from our previous paper, this work focuses on the galvanostatic preparation of $\mathrm{PbO}_{2}$ coatings on $\mathrm{RVC}\left(\mathrm{RVC} / \mathrm{PbO}_{2}\right)$ and $\mathrm{PbO}_{2}$ composites with titanium nanotubes $\left(\mathrm{RVC} / \mathrm{PbO}_{2} / \mathrm{TiNT}\right)$ using RVC of different porosities $(20,45,60,80$, and $100 \mathrm{ppi}-$ pores per inch) in MSA medium, and eventually test them for the EO of Methyl Orange solutions. The RVC porosity is a fundamental parameter to optimize the oxidation of water pollutants but, until now, the investigation of the effect of porosity has been limited to raw

21 RVC cathodes employed for the electrochemical removal of metal ions like $\mathrm{Cr}(\mathrm{VI}), \mathrm{Cu}(\mathrm{II})$ and $\mathrm{Zn}(\mathrm{II})$ [46-48] and for the deposition of $\mathrm{Cu}$ and $\mathrm{Ni}$ for $\mathrm{H}_{2}$ evolution [49]. Regarding the use of TiNT, a first approach was made in our previous work [44], reaching a certain 24 enhancement in the destruction of organic molecules. The surface analysis of the prepared coatings has been done by means of scanning electron microscopy (SEM) to elucidate their 
1 morphological characteristics, whereas the electrochemical characterisation was carried out

2 by cyclic voltammetry. Their potential application in EO has been assessed from colour and 3 total organic carbon (TOC) removal analyses.

\section{2. Experimental}

\subsection{Chemicals}

Reagent grade $\mathrm{Pb}(\mathrm{II})$ methanesulfonate $\left(\mathrm{Pb}\left(\mathrm{CH}_{3} \mathrm{SO}_{3}\right)_{2}\right.$, Aldrich, 50\%) and MSA $\left(\mathrm{CH}_{3} \mathrm{SO}_{3} \mathrm{H}, \quad\right.$ Aldrich, $\left.70 \%\right)$, as well as Methyl Orange azo dye (4-[4(dimethylamino)phenylazo]benzenesulfonic acid sodium salt, Fisher Scientific, > 99\%) were used without further purification. The TiNT were prepared via hydrothermal treatment of $\mathrm{TiO}_{2}$ (anatase, Aeroxide ${ }^{\circledR} \mathrm{TiO} 2 \mathrm{P} 25$ from Evonik Degussa) in $10 \mathrm{M} \mathrm{NaOH}$ at $140{ }^{\circ} \mathrm{C}$ for 24 $\mathrm{h}$, according to a modified procedure from the pioneering synthesis of nanotubular titanate $[50,51]$. They presented a specific surface area (BET, $\mathrm{N}_{2}$ desorption) and pore volume of ca. $200 \mathrm{~m}^{2} \mathrm{~g}^{-1}$ and $0.7 \mathrm{~cm}^{3} \mathrm{~g}^{-1}$, respectively. Analytical grade anhydrous sodium sulfate and sodium chloride were used as background electrolytes, whereas the initial $\mathrm{pH}$ of the solutions was adjusted with sodium hydroxyde and $\mathrm{H}_{2} \mathrm{SO}_{4}$. All reactants were purchased from Fisher Scientific and Fluka and all solutions were prepared with ultra-pure water with resistivity $>18$ $\mathrm{M} \Omega \mathrm{cm}\left(\right.$ at $\left.22.5^{\circ} \mathrm{C}\right)$, obtained from an Elga water purification system.

\subsection{Electrodeposition of $3 \mathrm{D}$-like raw $\mathrm{PbO}_{2}$ coatings and composite coatings}

The electrodeposition conditions for preparing the $\mathrm{RVC} / \mathrm{PbO}_{2}$ coatings were selected on the basis of our previous study aimed at optimising the obtention of perfect $\beta-\mathrm{PbO}_{2}$ deposits

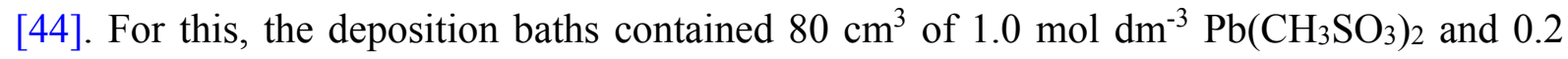
mol m $\mathrm{m}^{-3} \mathrm{MSA}$. The deposition was carried out at a constant current of $2.5 \mathrm{~A}$ for $30 \mathrm{~min}$ in a cylindrical, undivided glass cell thermostatized at $60{ }^{\circ} \mathrm{C}$ employing a Grant LT D6G water 
1 bath. The cell voltage was constant during the deposition experiments, i.e., 4 V. A similar

2 methodology was followed for the preparation of the $\mathrm{RVC} / \mathrm{PbO}_{2} / \mathrm{TiNT}$ composite coatings,

3 but it involved the co-deposition in the presence of $2.0 \mathrm{~g} \mathrm{dm}^{-3}$ of the freshly synthesized

4 TiNT.

RVC samples (ERG Materials) of different porosities (20, 45, 60, 80, and 100 ppi-

6 pores per inch) were used as the anode. Their volume was $8.8 \mathrm{~cm}^{3}$, exhibiting a parallelepiped 7 form (i.e., $4.7 \mathrm{~cm} \times 1.7 \mathrm{~cm} \times 1.1 \mathrm{~cm}$ ) with a surface area per unit volume that increased with 8 porosity from 13 to $65 \mathrm{~cm}^{-1}$ [10]. A platinum wire was inserted into each RVC and glued with

9 silver epoxy adhesive to ensure an optimum electrical contact. A cylindrical stainless steel mesh was used as the cathode. In all cases, the anode was placed in the centre of the 11 electrolytic cell, being completely surrounded by the cathode. Such a configuration favoured a proper current and potential distribution in the RVC substrates, ending in more homogeneous coatings. A fresh solution and anode were used for each experiment. The solution was magnetically stirred at $800 \mathrm{rpm}$ with a PTFE-coated magnetic follower to ensure reproducible mass transport conditions as well as to allow the dispersion of the TiNT.

\subsection{Electrochemical oxidation of Methyl Orange azo dye solutions}

Raw RVC samples as well as the electrodeposited materials described in the previous section were rinsed with ultra-pure water and dried. Then, they constituted the anodes for

19 treating azo dye solutions using an open, undivided glass cell with the same configuration described for the electrodeposition trials. Solutions of $275 \mathrm{~cm}^{3}$ of $0.25-0.50 \times 10^{-3} \mathrm{~mol} \mathrm{dm}^{-3}$

21 Methyl Orange in either $0.05 \mathrm{~mol} \mathrm{dm}^{-3} \mathrm{Na}_{2} \mathrm{SO}_{4}$ or $\mathrm{NaCl}$, as well as in mixed media, were electrolyzed at $0.6 \mathrm{~A}, \mathrm{pH} 3.0$ and $22.5^{\circ} \mathrm{C}$. The solution $\mathrm{pH}$ was very stable throughout the electrolyses. Vigorous stirring was provided by a magnetic follower. 
3 PGSTAT302N potentiostat/galvanostat from Autolab (EcoChemie, Netherlands) using the

4 Nova 1.7 software. The morphology and the thickness of all coatings were examined using a thermal field emission scanning electron microscope model JSM 6500F with an accelerating voltage of $15 \mathrm{kV}$. For the electrochemical characterisation, steady state cyclic voltammetry was carried out with the same Autolab PGSTAT302N instrument, using a purpose-built, three-electrode, undivided glass cell containing $50 \mathrm{~cm}^{3}$ of solution at $\mathrm{pH} 3.0$ and $22.5{ }^{\circ} \mathrm{C}$. A large area Pt gauze and $\mathrm{Ag}|\mathrm{AgCl}| \mathrm{KCl}$ (sat) were used as the counter and reference electrodes, respectively. The exposed area of the $\mathrm{RVC}, \mathrm{RVC} / \mathrm{PbO}_{2}$ and $\mathrm{RVC} / \mathrm{PbO}_{2} / \mathrm{TiNT}$ samples tested as working electrodes ranged between 113.1 and $565.5 \mathrm{~cm}^{2}$ (corresponding values for 20 and 100 ppi, respectively). All potentials in this paper are referred to the silver/silver chloride reference electrode potential.

The azo dye solutions were electrolysed using the same Autolab PGSTAT302N instrument, and various samples were withdrawn at regular intervals for futher analysis. The decolourisation of the dye solutions was evaluated from their absorbance $(A)$ decay at the maximum visible wavelength $\left(\lambda_{\max }\right)$ of $503 \mathrm{~nm}$, measured at $35^{\circ} \mathrm{C}$ on a Perkin Elmer Lambda UV/Vis spectrophotometer controlled by UV-WinLab Explorer software. The percentage of colour removal, also called decolorisation efficiency, could then be calculated as follows [17]:

$$
\text { Color removal }(\%)=\frac{A_{0}-A_{t}}{A_{0}} \times 100
$$
where $A_{0}$ and $A_{\mathrm{t}}$ are the initial absorbance that corresponding at time $t$ of the treatment. dissolved organic carbon, which corresponds to the TOC value because no heterogeneous organic matter was present in the solutions. This analytical parameter was determined on a 
1 Shimadzu VCSN analyzer. Samples were first microfiltered onto a hydrophilic membrane

2 (Millex-GV Millipore, pore size $0.22 \mu \mathrm{m}$ ), and then reproducible TOC values with $\pm 1 \%$

3 accuracy were found using the non-purgeable organic carbon method. The cell voltage was

4 continuously monitored on the Autolab to ensure that the coatings and electrical contact did

5 not become damage during the electrolyses.

\section{$6 \quad 3$. Results and Discussion}

\subsection{Surface characterisation of the $\mathrm{PbO}_{2}$-based coatings}

A series of three-dimensional raw $\mathrm{PbO}_{2}$ coatings $\left(\mathrm{RVC} / \mathrm{PbO}_{2}\right)$ as well as $\mathrm{RVC} / \mathrm{PbO}_{2} / \mathrm{TiNT}$ composite coatings was prepared by galvanostatic electrodeposition at 2.5 A and $60{ }^{\circ} \mathrm{C}$ for $30 \mathrm{~min}$. RVC with porosity ranging between 20 and 100 ppi was used as the

11 substrate, and SEM was employed for investigating the influence of porosity via a detailed morphological analysis. Some representative SEM images are shown in Fig. 1a-d. Note that the raw RVC molds exhibited a rigid honeycomb structure composed of carbonaceous strands assembled as so-called trigonal struts. The specific features of RVC samples with different pore sizes can be observed elsewhere [38]. Overall, the physical appearance of freshly-made materials was outstanding, with no traces of uncoated RVC along the outer surface. Furthermore, the coatings were highly uniform and adherent, since they could be handled without apparently forming any debris or leading to a flake-off of the $\mathrm{PbO}_{2}$ and $\mathrm{PbO}_{2} / \mathrm{TiNT}$ layers. Good uniformity and adherence mainly arise from the low resistivity of the RVC substrates [52], as well as from the adequate selection of the deposition conditions to

21 manufacture high quality $\mathrm{PbO}_{2}$-based networks, being produced at a lower cost than those prepared onto $\mathrm{Ti}$ or $\mathrm{Nb}$ grids.

The manufactured 3D-like electrodes exhibited a very well-attached metal oxide to the 24 RVC strips. Unlike the scarcely adherent coatings, no cracked-muddy surfaces with chunks 
1 were obtained under the selected deposition conditions. Their reticulated structure is clearly

2 evidenced in Fig. 1a-b. For example, the features of the RVC (20 ppi)/ $\mathrm{PbO}_{2}$ electrode are

3 shown in Fig. 1a, confirming the formation of a regular, continuous $\mathrm{PbO}_{2}$ coating covering

4 the RVC skeleton. The three-dimensionality is a key characteristic for minimising the mass

5 transport limitations that often appear when using planar high oxidation power anodes like

$6 \mathrm{PbO}_{2}$ plates or $\mathrm{BDD}$ thin films. Furthermore, being open-pore materials, the present 7 electrodes have a lower density than metallic grids, which is essential for obtaining 8 lightweight $\mathrm{PbO}_{2}$ anodes compared to traditional massive deposits. In Fig. 1b, a general view 9 of the whole structure of the RVC (60 ppi)/ $\mathrm{PbO}_{2}$ electrode is depicted, showing again the homogeneous coverage of the underlying RVC substrate. A higher magnification of the 11 previous image can be seen in Fig. 1c, which allows identifying the morphology of the grown $12 \mathrm{PbO}_{2}$ crystallites in this kind of electrodes. The coatings were composed of a compact but ragged structure containing large irregular or pyramidal-like features $10-15 \mu \mathrm{m}$ in height with obvious, sharp boundaries. This agrees with the recently reported microstructure of $\mathrm{PbO}_{2}$ deposited onto a planar carbon substrate under similar electrolytic conditions [36,37]. It can also be observed that the deposit was nanostructured, being composed of crystallites always in the range of a few nanometers (10-30 $\mathrm{nm}$ according to previous works on planar or 3D substrates $[36,44])$. A perfect surface coverage by $\mathrm{PbO}_{2}$ nanoelectrodeposits in an MSA bath was previously ascertained by SEM analysis for planar substrates [35-37]. Worth noting, the phase composition of the $\mathrm{RVC} / \mathrm{PbO}_{2}$ electrodes was not studied by $\mathrm{XRD}$, but previous 21 investigations in MSA reported the formation of pure $\beta$-phase when carrying out the deposition conditions at high applied current [34-37]. In fact, the morphology shown in Fig. 1c agrees very well with that expected for $\beta-\mathrm{PbO}_{2}$ coatings [36].

The second series of electrodes was prepared following a co-deposition procedure in the 25 presence of previously synthesized TiNT via the hydrothermal route, under the same 
1 electrolytic conditions described for the $\mathrm{RVC} / \mathrm{PbO}_{2}$ samples. As an example of the resulting 2 composite coatings, Fig. $1 \mathrm{~d}$ shows the SEM image of an RVC (60 ppi)/ $\mathrm{PbO}_{2} / \mathrm{TiNT}$ electrode.

3 As can be seen, high quality nanocomposites were obtained via the electrochemical synthesis

4 route, with titanate nanotubes being incorporated in the $\mathrm{PbO}_{2}$ matrix. More precisely, the 5 elongated TiNT appear well attached to the $\mathrm{PbO}_{2}$ nanocrystallites, thus giving rise to a 6 consistent heterogeneous surface with multiple potential properties derived from the presence 7 of both kinds of materials. All the RVC substrates presented such a mixed coverage with 8 TiNT bundles distributed along the surface, onto and among the crystallites. Since the TiNT 9 were tightly attached, they were not readily detachable. Consequently, the stability of the adsorbed titanate clusters allowed their subsequent utilization, as commented below.

Worth mentioning, only a few studies have reported the electrochemical co-deposition of either $\mathrm{PbO}_{2}$ and TiNT [44] or $\mathrm{PbO}_{2}$ and $\mathrm{TiO}_{2}$ particles [53] so far. Since TiNT are characterised by their high specific surface area, i.e., $200-300 \mathrm{~m}^{2} \mathrm{~g}^{-1}$, their presence may play a decisive role, as recently tested in the case of the EO of organic pollutants and the preparation of polypyrrol coatings with enhanced mechanical properties [44,45]. Regarding 16 the mechanism to explain the incorporation of the inert TiNT during the $\mathrm{PbO}_{2}$ electrocrystallisation process, a two-step adsorption was previsouly suggested [44]. This leads to the concomitant, strong immobilisation of TiNT that ensures that the final $\mathrm{RVC} / \mathrm{PbO}_{2} / \mathrm{TiNT}$ composite structure is long-lasting.

From the above findings, it is clear that, apparently, 3D-like $\mathrm{PbO}_{2}$ electrodes and 21 nanocomposites with a range of porosities and a good quality in terms of coating adhesion and surface coverage can be obtained following the proposed methodologies. Their dual use 23 for pollutant adsorption and oxidation by ${ }^{\circ} \mathrm{OH}$ is then expected to promote the 24 decontamination of water, as will be discussed below. However, first of all it is crucial to evaluate both, the thickness of the deposits and the quality of the coatings inside the pores. 
1 Fig. 2a-b show cross-sectional SEM images of RVC (60 ppi)/ $\mathrm{PbO}_{2}$ and $\mathrm{RVC}(100 \mathrm{ppi}) / \mathrm{PbO}_{2}$,

2 respectively. As can be seen, deposits of up to 60-70 $\mu \mathrm{m}$ thickness were formed on RVC of 60

3 ppi, whereas even thicker coatings were obtained on the external surface of RVC of 100 ppi.

4 Therefore, the use of MSA truly yields thicker coatings compared to traditional acidic media

5 [35]. Such thickness values are highly desirable for the use in water treatment because they

6 might ensure a greater protection of the underlying RVC structure. Interestingly, the deposits

7 proved to have a good adherence despite their considerable thickness, as mentioned above.

8 Measurements were made for all the $\mathrm{RVC} / \mathrm{PbO}_{2}$ coatings prepared, and Fig. 2c shows the

9 dependence of thickness of the $\mathrm{PbO}_{2}$ deposits (grown outward) with RVC porosity. An exponential increase of the thickness was found at a greater porosity, although the difference was less remarkable when comparing the electrodes of 20,45 and 60 ppi and much more evident when increasing the pore density over 60 ppi. Regarding the $\mathrm{RVC} / \mathrm{PbO}_{2} / \mathrm{TiNT}$ composites, a similar effect of porosity on the coating thickness was found (not shown). Slightly thicker coatings were achieved with those materials, which can be related to the positive influence of the nanosized titanate structures on the deposition kinetics of $\mathrm{PbO}_{2}$. Since they provide extra nucleation sites from produced Ti-O radical species, the rate of $\mathrm{PbO}_{2}$ electrodeposition and the final amount of grown $\mathrm{PbO}_{2}$ are enhanced [54]. In contrast to the apparent benefits derived from the increased RVC porosity, Fig. 2a-b also demonstrate that it can be detrimental since RVC can remain uncoated in the inner space of electrodes of porosity $>60 \mathrm{ppi}$, as revealed from cross-sectional analysis. The RVC (60 ppi)/ $\mathrm{PbO}_{2}$ was perfectly coated in the whole volume, whereas an inhomogeneous coating appeared in the RVC (100 ppi)/ $\mathrm{PbO}_{2}$ sample. This incomplete deposition onto the whole $\mathrm{RVC}$ will reduce the active area of the $\mathrm{PbO}_{2}$ anode to be used in $\mathrm{EO}$, as explained later on. Certainly, the faradaic efficiency was typically $90 \%$ in all cases, as determined by calculation of the deposition charge compared to gravimetric analysis, but the coverage of the RVC 
1 stripes was much more homogeneous for smaller pore sizes $(\leq 60 \mathrm{ppi})$. In other words, the

2 electrodeposits generated using RVC of 20-60 ppi presented a perfect distribution on the

3 surface and into the pores, whereas higher pore densities ( $>60 \mathrm{ppi})$ led to clogged pores that

4 prevented the growth of the $\mathrm{PbO}_{2}$ inward. As a result, a greater surface thickness was

5 obtained at 80 and 100 ppi (Fig. 2c). This finding is very relevant as for the use of these

6 electrodes for degrading organic pollutants because, actually, the $\mathrm{RVC} / \mathrm{PbO}_{2}$ and

$7 \mathrm{RVC} / \mathrm{PbO}_{2} / \mathrm{TiNT}$ electrodes that reached up to $120 \mu \mathrm{m}$ thicknesses can be essentially

8 considered as planar ones, whereas only the electrodes prepared with RVC of 20-60 ppi can

9 be defined as real homogeneous $3 \mathrm{D}$-like $\mathrm{PbO}_{2}$-based materials.

\subsection{Electrochemical characterisation of the $\mathrm{PbO}_{2}$-based coatings}

All the prepared $\mathrm{PbO}_{2}$-based electrodes but more particularly those considered to possess 3D-like structures were expected to be very suitable for the EO of pollutants because of their high specific surface area, which favours the contact between adsorbed organic molecules and the $\mathrm{M}\left({ }^{\bullet} \mathrm{OH}\right)$ formed via reaction (1). To investigate this aspect, the electrochemical characterisation of raw $\mathrm{RVC}$ as well as $\mathrm{RVC} / \mathrm{PbO}_{2}$ and $\mathrm{RVC} / \mathrm{PbO}_{2} / \mathrm{TiNT}$ electrodes was carried out by means of cyclic voltammetry. Fig. 3 shows the effect of RVC pores per inch on the maximum current $\left(I_{\max }\right)$ measured from the 5 th voltammogram recorded from $+1.4 \mathrm{~V}$ to $+2.0 \mathrm{~V}$ vs. $\mathrm{Ag}|\mathrm{AgCl}| \mathrm{KCl}$ (sat), in a $0.25 \times 10^{-3} \mathrm{~mol} \mathrm{dm}^{-3}$ Methyl Orange solution with $0.05 \mathrm{~mol} \mathrm{dm}^{-3} \mathrm{Na}_{2} \mathrm{SO}_{4}$, at $\mathrm{pH} 3.0$ and $22.5^{\circ} \mathrm{C}$. A steep current increase with no oxidation peaks appeared during the forward potential scan, which can be explained by the contribution of several anodic reactions, namely the oxidation of water to $\mathrm{O}_{2}$ and that of the azo dye to yield oxygenated by-products, as well as their immediate transformation, as was recently verified for its $\mathrm{EO}$ at $\mathrm{PbO}_{2}$ surfaces [37]. Note that, according to reaction (1), water oxidation reaction using high oxidation power anodes involves a first step yielding the 
1 oxidant $\mathrm{M}\left({ }^{\bullet} \mathrm{OH}\right)$ [12], which can in turn be responsible for the quicker degradation of the

2 initial pollutant and its intermediates.

According to Fig. 3, the electroactivity of the different electrodes within the range 20-80

4 ppi was as follows: $\mathrm{RVC} / \mathrm{PbO}_{2} / \mathrm{TiNT}>\mathrm{RVC} / \mathrm{PbO}_{2}>\mathrm{RVC}$. For all the samples, the value of

$5 I_{\max }$ increased when replacing 20 by 45 ppi, thus reaching a maximum and then, progressively lower current values were obtained when using higher porosity substrates. This confirms that coating the RVC stripes with $\mathrm{PbO}_{2}$ and $\mathrm{PbO}_{2}$ /TiNT is not only necessary for minimising the corrosion, but it also yields more electroactive materials, which at least partly contributes to the quicker oxidation of the organic molecules, both directly and via $\mathrm{M}\left({ }^{\bullet} \mathrm{OH}\right)$. For example, using a substrate of 45 ppi, current rised from 0.077 to 0.092 A upon $\mathrm{PbO}_{2}$ electrodeposition,

11 which is consistent with the much higher amount of active $\mathrm{M}\left({ }^{\bullet} \mathrm{OH}\right)$ generated at a high oxidation power anode like $\mathrm{PbO}_{2}$ or, in other words, with the better performance of $\mathrm{PbO}_{2}\left({ }^{\circ} \mathrm{OH}\right)$ compared with $\mathrm{RVC}\left({ }^{\bullet} \mathrm{OH}\right)$. Indeed, $\mathrm{PbO}_{2}$ anodes have a large oxygen evolution overpotential and hence, the oxidation of the azo dye and its intermediates is promoted over water oxidation at highly anodic potentials, thus enhancing the current efficiency referred to solution decontamination. The existence of a maximum $I_{\max }$ at 45 ppi can be explained as follows: 20 and 60 ppi RVC can be considered as 3D-like electrodes as well, as discussed from Fig. 1-2; however, 45 ppi constitutes the optimum porosity since it presents a larger surface area per unit volume compared to 20 ppi [10], and compared with $60 \mathrm{ppi}$, it allows both the easier penetration of dissolved $\mathrm{Pb}^{2+}$ and three-dimensional growth of $\mathrm{PbO}_{2}$ during the 21 electrodeposition process. In any case, $I_{\max }$ values were similar for 20-60 ppi, and all of them can be considered as $3 \mathrm{D}$-like $\beta$ - $\mathrm{PbO}_{2}$-based materials with optimal three-dimensionallity and nanocrystallinity. As explained from Fig. 2, substrates of 80 and 100 ppi presented a much smaller coated area, giving rise to planar-like electrodes. This allows justifying the lower $I_{\max }$ 
1 ppi, since the greatest $I_{\max }$ was obtained using the raw RVC electrode. This result clearly

2 confirms the negative effect of the diminished coated area when increasing the pore density,

3 yielding modified materials with blocked pores whose inner volume remains almost

4 completely inaccessible for the electrolyte. To confirm this hypothesis, it is interesting to note

5 that the current value obtained for the RVC ( $100 \mathrm{ppi}) / \mathrm{PbO}_{2}$ samples is very similar to that of a

6 planar $\mathrm{PbO}_{2}$ electrode prepared onto a carbon plate [36].

A similar influence of porosity on $I_{\max }$ can be observed in Fig. 3 for the $\mathrm{RVC} / \mathrm{PbO}_{2} / \mathrm{TiNT}$ electrodes, but significantly greater values were obtained, reaching a greatest $I_{\max }>0.13$ A using 45 ppi (ca. 70\% higher current than that obtained with raw RVC), with similar values for 20 and 60 ppi. It is then evident the positive contribution of the TiNT in the EO process. Such enhancement can be preeminently related to the synergistic action between the greater adsorption of the dye molecules and some reaction intermediates in the presence of the agglomerates of titanate nanotubes along with their EO by the $\mathrm{PbO}_{2}\left({ }^{\bullet} \mathrm{OH}\right)$.

14 The action of these oxidising radicals is thus favoured when employing the composite anodes, since the organic molecules become more largely adsorbed upon contact with the large surface area $\beta-\mathrm{PbO}_{2}$ nanocrystallites and the TiNT. Is worth to mention that the positive $I_{\max }$ at all porosities demonstrates that the greater number of adsorption sites did not cause anode fouling by the organics or potential polimerisation derivatives, which is an evidence of the simulatenous oxidative action of the $\mathrm{PbO}_{2}\left({ }^{\bullet} \mathrm{OH}\right)$ at highly positive potentials.

\subsection{Electro-oxidation of Methyl Orange solutions}

Once confirmed that the coating of RVC yielded various electrodes that could potentially exhibit a much better performance regarding the EO of organic molecules, all the $\mathrm{PbO}_{2}$-coated carbonaceous electrodes were used as the anodes to perform a protracted $\mathrm{EO}$ of $0.25 \times 10^{-3} \mathrm{~mol} \mathrm{dm}^{-3}$ Methyl Orange solutions with $0.05 \mathrm{~mol} \mathrm{dm}^{-3} \mathrm{Na}_{2} \mathrm{SO}_{4}$, at $0.6 \mathrm{~A}, \mathrm{pH} 3.0$ 
1 and $22.5{ }^{\circ} \mathrm{C}$ using a stainless steel mesh as the cathode. It is worth noting that Tang and Kong

2 obtained $>90 \%$ colour removal at times longer than 100 min when they degraded $0.16 \times 10^{-3}$

$3 \mathrm{~mol} \mathrm{dm}{ }^{-3}$ Methyl Orange by EO at $25 \mathrm{~mA} \mathrm{~cm}$ contained in $200 \mathrm{~cm}^{3}$ of electrolyte using

4 various planar doped- $\beta-\mathrm{PbO}_{2}$-coated Ti anodes [29].

Fig. 4a-b shows the influence of the RVC porosity on the percentage of color removal vs. time during the electrolyses using $\mathrm{RVC} / \mathrm{PbO}_{2}$ and $\mathrm{RVC} / \mathrm{PbO}_{2} / \mathrm{TiNT}$ anodes, respectively. The trials were also carried out with raw RVC anodes but, as expected, they became severily degraded. Conversely, all the coated anodes led to $>98 \%$ absorbance decay in $45 \mathrm{~min}$, with no presence of carbon in solution thanks to the good isolation of the carbonaceous substrates. In Fig. 4a, it can be seen that $\mathrm{RVC}(45 \mathrm{ppi}) / \mathrm{PbO}_{2}$ yielded the quickest decolourisation during 11 the first $10 \mathrm{~min}$ of electrolysis. For example, after $2.5 \mathrm{~min}, 50 \%$ colour removal was achieved instead of ca. $40 \%$ reached with the other anodes. The superiority exhibited at this porosity can be related to the greater electroactive area discussed from Fig. 3 . From 15 min, the results became quite similar for all the electrodes, which can be explained by the appearance and adsorption of degradation by-products that were simulataneously oxidized by $\mathrm{PbO}_{2}\left({ }^{\bullet} \mathrm{OH}\right)$, thus decelerating the removal of the initial dye. Note that even the RVC (100 ppi)/ $\mathrm{PbO}_{2}$ anode, whose electroactivity was lower due to the smaller coated area, was able to reach the complete colour removal at $60 \mathrm{~min}$. This suggests that large amounts of active $\mathrm{PbO}_{2}\left({ }^{\circ} \mathrm{OH}\right)$ are generated even with the sole participation of the external surface.

As can be observed in Fig. 4b, composite anodes yielded a faster decolourisation of Methyl Orange solutions, especially those of 20-60 ppi. Again, $>98 \%$ absorbance decay was attained at $45 \mathrm{~min}$ in all cases but, at $2.5 \mathrm{~min}$, the $\mathrm{RVC}(45 \mathrm{ppi}) / \mathrm{PbO}_{2} / \mathrm{TiNT}$ anode yielded the quickest decolourisation (60\%) among all the electrodes. The superiority of this material was evident up to $10 \mathrm{~min}$, as discussed above for the $\mathrm{RVC} / \mathrm{PbO}_{2}$. This finding confirms that the TiNT really act as an important anchorage site for the organics, thus enhancing the efficiency 
1 of $\mathrm{PbO}_{2}\left({ }^{\bullet} \mathrm{OH}\right)$ to cause their progressive degradation. The reaction kinetics using 80 and 100

2 ppi was not significantly enhanced, as expected from their much lower electroactivity (Fig. 3).

3 In fact, the presence of TiNT appears to be detrimental in these two cases if compared with

4 Fig. 4a, which can be explained by the excessive blockage of $\mathrm{PbO}_{2}$ sites, thus resulting in a

5 lower accumulation of active $\mathrm{PbO}_{2}\left({ }^{\circ} \mathrm{OH}\right)$. In conclusion, the RVC (45 ppi)/ $\mathrm{PbO}_{2} / \mathrm{TiNT}$ anodes yielded the largest decolorisation efficiency and thus, they were used for investigating the effect of Methyl Orange concentration and electrolyte composition on colour and TOC removal, as compared with $\mathrm{RVC}(20 \mathrm{ppi}) / \mathrm{PbO}_{2} / \mathrm{TiNT}$.

Fig. 5a depicts the effect of Methyl Orange content on the percentage of colour removal vs. time during the electrolyses of dye solutions with $0.05 \mathrm{~mol} \mathrm{dm}^{-3} \mathrm{Na}_{2} \mathrm{SO}_{4}$, at $0.6 \mathrm{~A}, \mathrm{pH} 3.0$ and $22.5{ }^{\circ} \mathrm{C}$ using an $\mathrm{RVC}(20 \mathrm{ppi}) / \mathrm{PbO}_{2} / \mathrm{TiNT}$ or $\mathrm{RVC}(45 \mathrm{ppi}) / \mathrm{PbO}_{2} / \mathrm{TiNT}$ anode. The much slower absorbance decay when treating $0.50 \times 10^{-3} \mathrm{~mol} \mathrm{dm}^{-3}$ Methyl Orange is evident with both anodes. Certainly, $>98 \%$ colour removal was attained at $45 \mathrm{~min}$ in all cases but, at $10 \mathrm{~min}, 84 \%$ and $57 \%$ was reached from solutions containing 0.25 and $0.50 \times 10^{-3} \mathrm{~mol} \mathrm{dm}^{-3}$ dye, respectively. The acceleration during the first minutes at the lowest content can then be related to the smaller extent of simultaneous oxidation reactions of intermediates, yielding larger amounts of $\mathrm{PbO}_{2}\left({ }^{\bullet} \mathrm{OH}\right)$ readily available to degrade the dye. The electrolyses were extended for several hours in order to obtain information on the behaviour of TOC (not shown). The RVC (45 ppi)/ $\mathrm{PbO}_{2} / \mathrm{TiNT}$ anode was a good material not only to provide the complete decolourisation of solutions in less than $60 \mathrm{~min}$, but also to gradually mineralise them. For example, at $240 \mathrm{~min}, 55 \%$ and $60 \%$ TOC abatement was reached for solutions containing 0.25 and $0.50 \times 10^{-3} \mathrm{~mol} \mathrm{dm}^{-3}$ Methyl Orange (initial TOC of 42 and $84 \times 10^{-3} \mathrm{~g} \mathrm{C}$ $\mathrm{dm}^{-3}$ ), respectively. This means that, although a larger number of organic molecules has to be degraded starting at a higher dye content, the $\mathrm{PbO}_{2}\left({ }^{\circ} \mathrm{OH}\right)$ act more efficiently on them because parasitic reactions involving radicals (i.e., self-destruction, reaction with inorganic ions) 
1 become minimised. This also justifies the slower decolourisation kinetics shown in Fig. 5a.

2 This can also be demonstrated from the higher mineralization current efficiency (MCE) and

3 lower energy consumption per unit TOC mass (ЕСТос) for the electrolyses with larger dye

4 content, as calculated from the equations provided elsewhere [20,55]. MCE was $2.6 \%$ and

$5 \quad 5.7 \%$, whereas EC $\mathrm{E}_{\mathrm{TOC}}$ was 1.5 and $0.69 \mathrm{kWh}\left(\mathrm{g}\right.$ TOC) ${ }^{-1}$ for electrolyses with 0.25 and $0.50 \times$

$6 \quad 10^{-3} \mathrm{~mol} \mathrm{dm}^{-3}$ Methyl Orange, respectively.

$7 \quad$ Fig. $5 b$ reveals the very positive influence of the presence of $\mathrm{NaCl}$ in the supporting 8 electrolyte on color removal for the treatment of $0.25 \times 10^{-3} \mathrm{~mol} \mathrm{dm}^{-3}$ Methyl Orange 9 solutions using the $\mathrm{RVC}(45 \mathrm{ppi}) / \mathrm{PbO}_{2} / \mathrm{TiNT}$ anode at $0.6 \mathrm{~A}$. The absorbance decay was extremely fast when $0.05 \mathrm{~mol} \mathrm{dm}^{-3} \mathrm{NaCl}$ or mixtures with $0.05 \mathrm{~mol} \mathrm{dm}^{-3} \mathrm{Na}_{2} \mathrm{SO}_{4}$ were employed, achieving $>95 \%$ decolourisation at $2.5 \mathrm{~min}$. This fact can be related to the generation of active chlorine, a very powerful bleaching agent, upon oxidation of $\mathrm{Cl}^{-}$anion at $\mathrm{PbO}_{2}[5,12]$, and opens the door to the application of this kind of composite anodes to the treatment of industrial wastewater where $\mathrm{Cl}^{-}$and $\mathrm{SO}_{4}{ }^{2-}$ anions tend to be present, as in the case of dye wastewater [5].

\section{Conclusions}

This work demonstrates the key influence exerted by the substrate porosity when preparing three-dimensional pure $\mathrm{PbO}_{2}$ coatings and composites with TiNT onto RVC. Although all the electrodes led to the total decolourisation of dye solutions, only those manufactured using RVC of 20-60 ppi ensured a complete isolation of the substrate that prevented the material destruction upon prolonged electrolyses. Among them, the RVC (45 $\mathrm{ppi} / \mathrm{PbO}_{2} / \mathrm{TiNT}$ anodes have shown the best performance in terms of solution decontamination, which arises from their optimum coating thickness and $\mathrm{PbO}_{2} / \mathrm{TiNT}$ distribution along the whole volume. The elongated TiNT enhances the adsorption of organic 
1 molecules, which are then more efficiently degraded by $\mathrm{PbO}_{2}\left({ }^{\bullet} \mathrm{OH}\right)$, as demonstrated by the

2 fast decolourisation and the significant mineralisation of dye solutions at ca. 45 and $240 \mathrm{~min}$, 3 respectively. Therefore, these $3 \mathrm{D}$-like $\beta-\mathrm{PbO}_{2}$ anodes constitute suitable materials to

4 minimise the mass transport limitations that typically appear when employing commercial 5 plates, and could potentially serve as cheaper large surface electrodes for industrial 6 wastewater treatment.

\section{Acknowledgments}

8 The authors thank MINECO (Spain) for financial support under project CTQ20139 48897-C2-1-R, co-financed with FEDER funds. CPDL thanks the International Office of the 10 University of Southampton through their Southampton-FAPESP scholarship and Banco 11 Santander for their financial support. The authors gratefully acknowledge Dmitry Bavykin 12 and Alex Kulak for providing the TiNT used in this paper. 
[1] D. Seckler, U. Amarasinghe, D. Molden, R. De Silva, R. Barker, World water demand and supply, 1990 to 2025: Scenarios and issues, International Irrigation Management Institute (IIMI), IIMI Research Report 19, Colombo, Sri Lanka, 1998.

[2] V.V. Ranade, V.M. Bhandari, Industrial Wastewater Treatment, Recycling and Reuse, Butterworth-Heinemann/Elsevier Science, 2014.

[3] M.A. Rodrigo, N. Oturan, M.A. Oturan, Electrochemically assisted remediation of pesticides in soils and water: A review, Chem. Rev. 114 (2014) 8720.

[4] E. Brillas, I. Sirés, Electrochemical removal of pharmaceuticals from water streams: Reactivity elucidation by mass spectrometry, TrAC - Trends Anal. Chem. 70 (2015) 112.

[5] E. Brillas, C.A. Martínez-Huitle, Decontamination of wastewaters containing synthetic organic dyes by electrochemical methods. An updated review, Appl. Catal. B- Environ. 166-167 (2015) 603.

[6] K. Singh, S. Arora, Removal of synthetic textile dyes from wastewaters: a critical review on present treatment tecnologies, Crit. Rev. Environ. Sci. Technol. 41(9) (2011) 807.

[7] M.M. Dávila-Jiménez, M.P. Elizalde-González, V. Hernández-Montoya, Performance of mango seed adsorbents in the adsorption of anthraquinone and azo acid dyes in single and binary aqueous solutions, Biores. Technol. 100 (2009) 6199.

[8] Y.Y. Lau, Y.S. Wong, T.T. Teng, N. Morad, M. Rafatullah, S.A. Ong, Coagulationflocculation of azo dye Acid Orange 7 with green refined laterite soil, Chem. Eng. J. 246 (2014) 383. 
1 [9] S. Figueroa, L. Vázquez, A. Álvarez-Gallegos, Decolorizing textile wastewater with 2 Fenton's reagent electrogenerated with a solar photovoltaic cell, Water Res. 43 (2009) 283.

[10] I. Sirés, E. Brillas, M.A. Oturan, M.A. Rodrigo, M. Panizza, Electrochemical advanced oxidation processes: today and tomorrow. A review, Environ. Sci. Pollut. Res. 21 (2014) 8336.

[11] M. Panizza, G. Cerisola, Electrochemical degradation of methyl red using BDD and PbO2 anodes, Ind. Eng. Chem. Res. 47 (2008) 6816.

[12] M. Panizza, G. Cerisola, Direct and mediated anodic oxidation of organic pollutants, Chem. Rev. 109 (2009) 6541.

[13] J.M. Aquino, M.A. Rodrigo, R.C. Rocha-Filho, C. Sáez, P. Cañizares, Electrochemical degradation of the Reactive Red 141 dye using a boron-doped diamond anode, Water Air Soil Pollut. 224 (2013) 1397.

[14] R. Chaiyont, C. Badoe, C. Ponce de León, J.L. Nava, F.J. Recio, I. Sirés, P. Herrasti, F.C. Walsh, Decolorization of methyl orange dye at $\mathrm{IrO}_{2}-\mathrm{SnO}_{2}-\mathrm{Sb}_{2} \mathrm{O}_{5}$ coated titanium anodes, Chem. Eng. Technol. 36 (2013) 123.

[15] A. El-Ghenymy, F. Centellas, J.A. Garrido, R.M. Rodríguez, I. Sirés, P.L. Cabot, E. Brillas, Decolorization and mineralization of Orange $G$ azo dye solutions by anodic oxidation with a boron-doped diamond anode in divided and undivided tank reactors, Electrochim. Acta 130 (2014) 568.

[16] O. Scialdone, A. Galia, S. Sabatino, Abatement of Acid Orange 7 in macro and micro reactors. Effect of the electrocatalytic route, Appl. Catal. B- Environ. 148-149 (2014) 473.

[17] A. El-Ghenymy, F. Centellas, R.M. Rodríguez, P.L. Cabot, J.A. Garrido, I. Sirés, E. Brillas, Comparative use of anodic oxidation, electro-Fenton and photoelectro-Fenton 
with Pt or boron-doped diamond anode to decolorize and mineralize Malachite Green oxalate dye, Electrochim. Acta 182 (2015) 247.

[18] A. Thiam, E. Brillas, F. Centellas, P.L. Cabot, I. Sirés, Electrochemical reactivity of Ponceau 4R (food additive E124) in different electrolytes and batch cells, Electrochim. Acta 173 (2015) 523.

[19] A. Thiam, I. Sirés, J.A. Garrido, R.M. Rodríguez, E. Brillas, Decolorization and mineralization of Allura Red $\mathrm{AC}$ aqueous solutions by electrochemical advanced oxidation processes, J. Hazard. Mater. 290 (2015) 34.

[20] A. Thiam, I. Sirés, J.A. Garrido, R.M. Rodríguez, E. Brillas, Effect of anions on electrochemical degradation of azo dye Carmoisine (Acid Red 14) using a BDD anode and air-diffusion cathode, Sep Purif. Technol. 140 (2015) 43.

[21] X. Ma, M. Zhou, A comparative study of azo dye decolorization by electro-Fenton in two common electrolytes, J. Chem. Technol. Biotechnol. 84 (2009) 1544.

[22] A. Özcan, M.A. Oturan, N. Oturan, Y. Şahin, Removal of Acid Orange 7 from water by electrochemically generated Fenton's reagent, J. Hazard. Mater. 163 (2009) 1213.

[23] E.J. Ruiz, C. Arias, E. Brillas, A. Hernández-Ramírez, J.M. Peralta-Hernández, Mineralization of Acid Yellow 36 azo dye by electro-Fenton and solar photoelectroFenton processes with a boron-doped diamond anode, Chemosphere 82 (2011) 495.

[24] W. Wu, Z.H. Huang, T.T. Lim, Recent development of mixed metal oxide anodes for electrochemical oxidation of organic pollutants in water, Appl. Catal. A-General 480 (2014) 58.

[25] C.A. Martínez-Huitle, M.A Rodrigo, I. Sirés, O. Scialdone, Single and coupled electrochemical processes and reactors for the abatement of organic water pollutants: A critical review, Chem.Rev. 115 (2015) 13362. 
1 [26] C. Comninellis, Electrocatalysis in the electrochemical conversion/combustion of organic pollutants for waste water treatment, Electrochim. Acta 39 (1994) 1857.

[27] I. Sirés, E. Brillas, G. Cerisola, M. Panizza, Comparative depollution of mecoprop aqueous solutions by electrochemical incineration using $\mathrm{BDD}$ and $\mathrm{PbO}_{2}$ as high oxidation power anodes, J. Electroanal. Chem. 613 (2008) 151.

[28] X. Li, D. Pletcher, F.C. Walsh, Electrodeposited lead dioxide coatings, Chem. Soc. Rev. 40 (2011) 3879.

[29] Y. Tang, C. Kong, A preliminary study on electrodeposition and decolorization activity of $\beta-\mathrm{PbO}_{2}$-coated titanium electrodes from tetrafluoroborate solutions, Mater. Chem. Phys. 135 (2012) 1108.

[30] H. An, H. Cui, W. Zhang, J. Zhai, Y. Qian, X. Xie, Q. Li, Fabrication and electrochemical treatment application of a microstructured $\mathrm{TiO}-\mathrm{NTs} / \mathrm{Sb}-\mathrm{SnO}_{2} / \mathrm{PbO}_{2}$ anode in the degradation of CI Reactive Blue 194 (RB 194), Chem. Eng. J. 209 (2012) 86.

[31] S. Song, J. Fan, Z. He, L. Zhan, Z. Liu, J. Chen, X. Xu, Electrochemical degradation of azo dye CI Reactive Red 195 by anodic oxidation on $\mathrm{Ti} / \mathrm{SnO} 2-\mathrm{Sb} / \mathrm{PbO}_{2}$ electrodes, Electrochim. Acta 55 (2010) 3606.

[32] S. Ghasemi, M.F. Mousavi, M. Shamsipur, Electrochemical deposition of lead dioxide in the presence of polyvinylpyrrolidone: a morphological study, Electrochim. Acta 53 (2007) 459.

[33] X. Duan, F. Ma, Z. Yuan, L. Chang, X. Jin, Lauryl benzene sulfonic acid sodium-carbon nanotube-modified $\mathrm{PbO}_{2}$ electrode for the degradation of 4-chlorophenol, Electrochim. Acta 76 (2012) 333.

[34] M.D. Gernon, M. Wu, T. Buszta, P. Janney, Environmental benefits of methanesulfonic acid. Comparative properties and advantages, Green Chem. 1 (1999) 127. 
1 [35] A.B. Velichenko, R. Amadelli, E.V. Gruzdeva, T.V. Luk'yanenko, F.I. Danilov, Electrodeposition of lead dioxide from methanesulfonate solutions, J. Power Sources $191(2009) 103$.

[36] I. Sirés, C.T.J. Low, C. Ponce-de-León, F.C. Walsh, The characterisation of $\mathrm{PbO}_{2}-$ coated electrodes prepared from aqueous methanesulfonic acid under controlled deposition conditions, Electrochim. Acta 55 (2010) 2163.

[37] I. Sirés, C.T.J. Low, C. Ponce-de-León, F.C. Walsh, The deposition of nanostructured $\beta-\mathrm{PbO}_{2}$ coatings from aqueous methanesulfonic acid for the electrochemical oxidation of organic pollutants, Electrochem. Commun. 12 (2010) 70.

[38] J.M. Friedrich, C. Ponce-de-León, G.W. Reade, F.C. Walsh, Reticulated vitreous carbon as an electrode material, J. Electroanal. Chem. 561 (2004) 203.

[39] A.M. Couper, D. Pletcher, F.C. Walsh, Electrode materials for electrosynthesis, Chem. Rev. 90 (1990) 837.

[40] F.C. Walsh, A first course in electrochemical engineering, The Electrochemical Consultancy Ltd., Romsey, England, 1993.

[41] J.L. Nava, I. Sirés, E. Brillas, Electrochemical incineration of indigo. A comparative study between 2D (plate) and 3D (mesh) BDD anodes fitted into a filter-press reactor, Environ. Sci. Pollut. Res. 21 (2014) 8485.

[42] C. Zhang, Y. Jiang, Y. Li, Z. Hu, L. Zhou, M. Zhou, Three-dimensional electrochemical process for wastewater treatment: A general review, Chem. Eng. J. 228 (2013) 455.

[43] H. Liu, A. Vajpayee, C. Vecitis, Bismuth-doped tin oxide-coated carbon nanotube network: improved anode stability and efficiency for flow-through organic electrooxidation, ACS Appl. Mater. Interfaces 5 (2013) 10054. 
1 [44] F.J. Recio, P. Herrasti, I. Sirés, A.N. Kulak, D.V. Bavykin, C. Ponce-de-León, F.C. Walsh, The preparation of $\mathrm{PbO}_{2}$ coatings on reticulated vitreous carbon for the electrooxidation of organic pollutants, Electrochim. Acta 56 (2011) 5158.

[45] S. Chai, G. Zhao, Y. Wang, Y.-N. Zhang, Y. Wang, Y. Jin, X. Huang, Fabrication and enhanced electrocatalytic activity of $3 \mathrm{D}$ highly ordered macroporous $\mathrm{PbO}_{2}$ electrode for recalcitrant pollutant incineration, Appl. Catal. B- Environ. 147 (2014) 275.

[46] M.R.V. Lanza, R. Bertazzoli, Removal of Zn (II) from chloride medium using a porous electrode: current penetration within the cathode, J. Appl. Electrochem. 30 (2000) 61.

[47] F. Rodríguez-Valadez, C. Ortiz-Éxiga, J.G. Ibañez, A. Alatorre-Ordaz, S. GutierrezGranados, Electroreduction of $\mathrm{Cr}$ (VI) to $\mathrm{Cr}$ (III) on reticulated vitreous carbon electrodes in a parallel-plate reactor with recirculation, Environ. Sci. Technol. 39 (2005) 1875.

[48] G.W. Reade, A.H. Nahle, P. Bond, J.M. Friedrich, F.C. Walsh, Removal of cupric ions from acidic sulfate solution using reticulated vitreous carbon rotating cylinder electrodes, J. Chem. Technol. Biotechnol. 79 (2004) 935.

[49] M.M. Saleh, M.H. El-Ankily, M.S. El-Deab, B.E. El-Anadouli, Electrocatalytic activity of metal-loaded reticulated vitreous carbon electrodes for hydrogen evolution from flowing alkaline solutions, Bull. Chem. Soc. Jpn. 79 (2006) 1711.

[50] T. Kasuga, M. Hiramatsu, A. Hoson, T. Sekino, K. Niihara, Formation of titanium oxide nanotube, Langmuir 14 (1998) 3160.

[51] D.V. Bavykin, F.C. Walsh, Titanate and Titania Nanotubes: Synthesis, Properties and Applications, Royal Society of Chemistry, Cambridge, 2010.

[52] A. Czerwiński, Z. Rogulski, Sz. Obrębowski, H. Siwek, I. Paleska, M. Chotkowski, M. Łukaszewski, RVC as new carbon material for batteries, J. Appl. Electrochem. 39 (2009) 559. 
1 [53] A.B. Velichenko, R. Amadelli, V.A. Knysh, T.V. Luk'yanenko, F.I. Danilov, Kinetics of lead dioxide electrodeposition from nitrate solutions containing colloidal $\mathrm{TiO}_{2}, \mathrm{~J}$. Electroanal. Chem. 632 (2009) 192.

4 [54] G.M. de Oliveira, I.A. Carlos, Silver-zinc electrodeposition from a thiourea solution 5 with added EDTA or HEDTA, Electrochim. Acta 54 (2009) 2155.

6 [55] J.A. Bañuelos, A. El-Ghenymy, F.J. Rodríguez, J. Manríquez, E. Bustos, A. Rodríguez, E. Brillas, L.A. Godínez, Study of an air diffusion activated carbon packed electrode for an electro-fenton wastewater treatment, Electrochim. Acta 140 (2014) 412. 


\section{Figure captions}

2 Figure 1. SEM images of coatings prepared on RVC from solutions containing $1.0 \mathrm{~mol} \mathrm{dm}^{-3}$ $3 \mathrm{~Pb}\left(\mathrm{CH}_{3} \mathrm{SO}_{3}\right)_{2}$ and $0.2 \mathrm{~mol} \mathrm{dm}{ }^{-3} \mathrm{MSA}$ at $2.5 \mathrm{~A}$ and $60{ }^{\circ} \mathrm{C}$ for $30 \mathrm{~min}$ in the absence

$4 \quad\left(\mathrm{RVC} / \mathrm{PbO}_{2}\right)$ or presence $\left(\mathrm{RVC} / \mathrm{PbO}_{2} / \mathrm{TiNT}\right)$ of previously synthesized TiNT: (a) RVC (20

5 ppi)/ $/ \mathrm{PbO}_{2}$; (b) RVC (60 ppi)/ $\mathrm{PbO}_{2}$; (c) Magnified image from coating shown in (b); (d) RVC $6 \quad(60 \mathrm{ppi}) / \mathrm{PbO}_{2} / \mathrm{TiNT}$ coating.

7 Figure 2. SEM images of cross sections of (a) RVC (60 ppi)/ $\mathrm{PbO}_{2}$ and (b) $\mathrm{RVC}(100$

$8 \mathrm{ppi} / \mathrm{PbO}_{2}$, and (c) dependence of thickness of $\mathrm{PbO}_{2}$ deposit with $\mathrm{RVC}$ porosity for all the $9 \mathrm{RVC} / \mathrm{PbO}_{2}$ coatings prepared.

Figure 3. Effect of RVC porosity on the maximum current measured from cyclic voltammograms (5th cycle) recorded at the $\mathrm{RVC}, \mathrm{RVC} / \mathrm{PbO}_{2}$ and $\mathrm{RVC} / \mathrm{PbO}_{2} / \mathrm{TiNT}$ electrodes from $+1.4 \mathrm{~V}$ to $+2.0 \mathrm{~V}$, in a $0.25 \times 10^{-3} \mathrm{~mol} \mathrm{dm}^{-3}$ Methyl Orange solution with $0.05 \mathrm{~mol} \mathrm{dm} \mathrm{d}^{-3}$ $\mathrm{Na}_{2} \mathrm{SO}_{4}$, at $\mathrm{pH} 3.0$ and $22.5^{\circ} \mathrm{C}$. Potential sweep rate: $10 \mathrm{mV} \mathrm{s}^{-1}$. Counter electrode: Pt gauze. Reference electrode: $\mathrm{Ag}|\mathrm{AgCl}| \mathrm{KCl}$ (sat.).

Figure 4. Influence of the RVC porosity on the percentage of colour removal vs. time during the electrolyses of $0.25 \times 10^{-3} \mathrm{~mol} \mathrm{dm}^{-3}$ Methyl Orange solutions with $0.05 \mathrm{~mol} \mathrm{dm}^{-3} \mathrm{Na}_{2} \mathrm{SO}_{4}$, at $0.6 \mathrm{~A}$, pH 3.0 and $22.5{ }^{\circ} \mathrm{C}$ using a stainless steel mesh as the cathode and different RVCcoated anodes: (a) $\mathrm{RVC} / \mathrm{PbO}_{2}$; (b) $\mathrm{RVC} / \mathrm{PbO}_{2} / \mathrm{TiNT}$.

Figure 5. (a) Effect of Methyl Orange concentration on the percentage of colour removal vs. time during the electrolyses of dye solutions with $0.05 \mathrm{~mol} \mathrm{dm}^{-3} \mathrm{Na}_{2} \mathrm{SO}_{4}$, at $0.6 \mathrm{~A}$, pH 3.0 and $22.5^{\circ} \mathrm{C}$ using a stainless steel mesh as the cathode and an RVC (20 ppi)/ $\mathrm{PbO}_{2} / \mathrm{TiNT}$ or RVC (45 ppi)/ $/ \mathrm{PbO}_{2} / \mathrm{TiNT}$ anode. (b) Influence of the supporting electrolyte (each salt at 
1 concentration of $0.05 \mathrm{~mol} \mathrm{dm}^{-3}$ ) on colour removal for the treatment of $0.25 \times 10^{-3} \mathrm{~mol} \mathrm{dm}^{-3}$

2 Methyl Orange solutions using the RVC (45 ppi)/ $/ \mathrm{PbO}_{2} / \mathrm{TiNT}$ anode.

3

4

5

6

7

8

9

10

11

12

13

14

15

16

17

18 

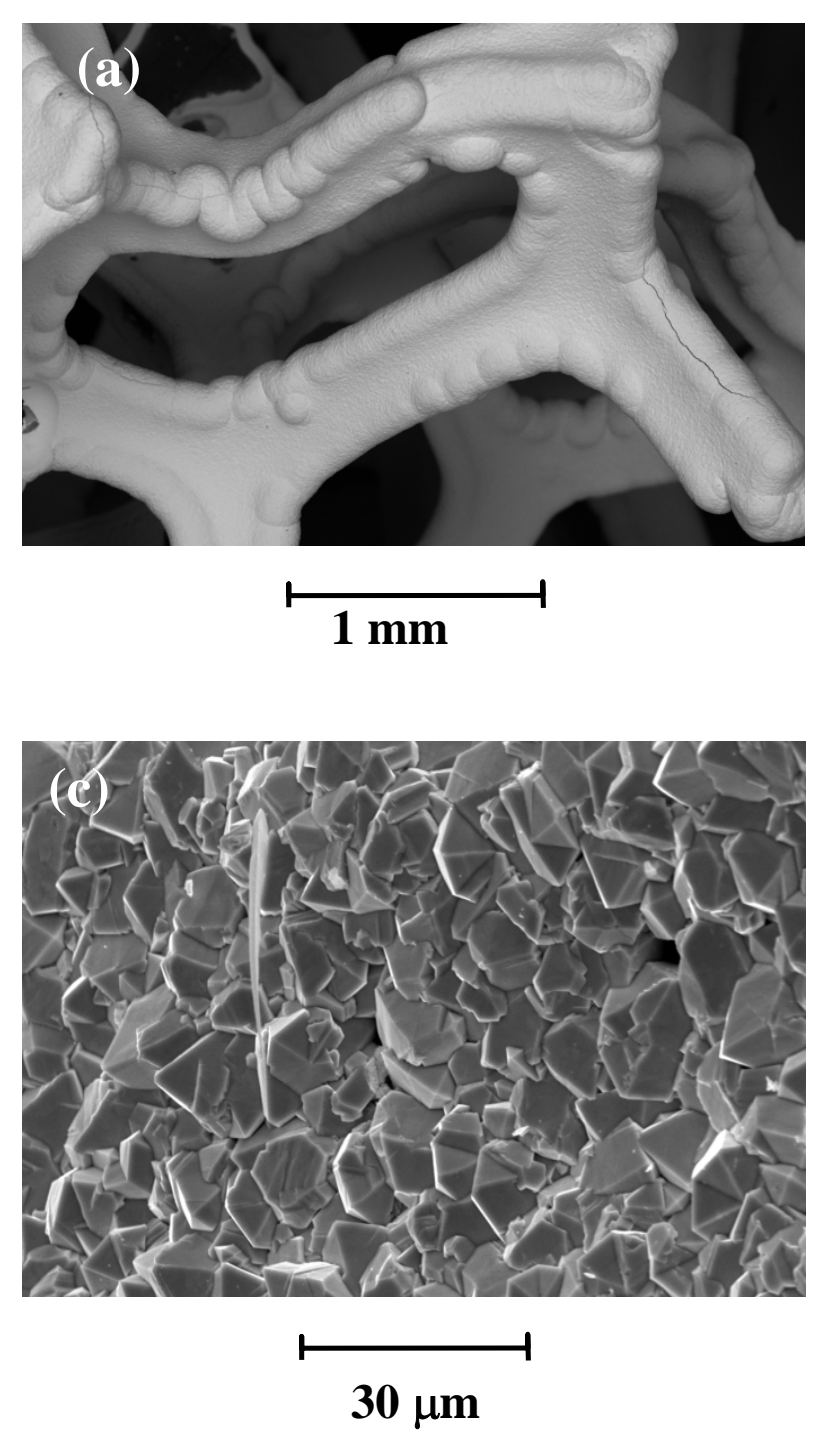
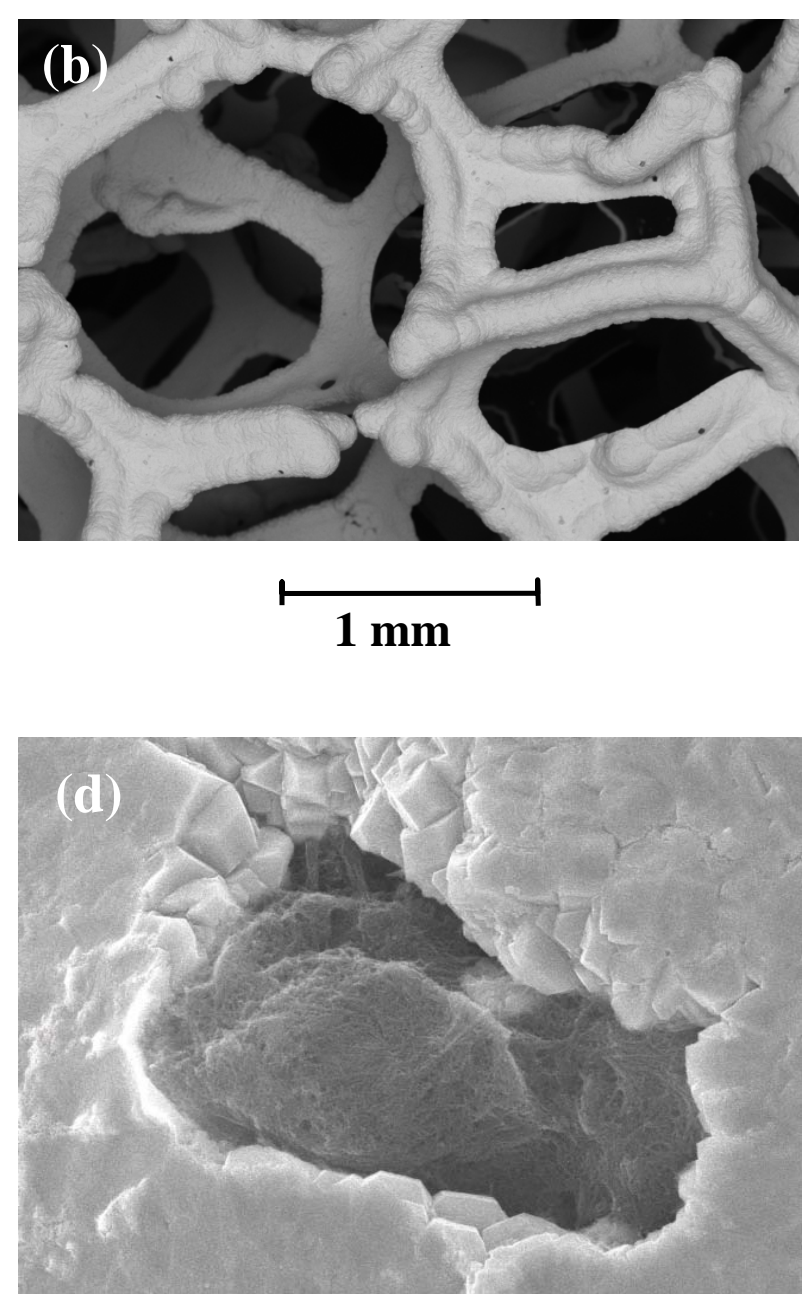

$1 \stackrel{\longmapsto m}{\mu \mathrm{m}}$ 


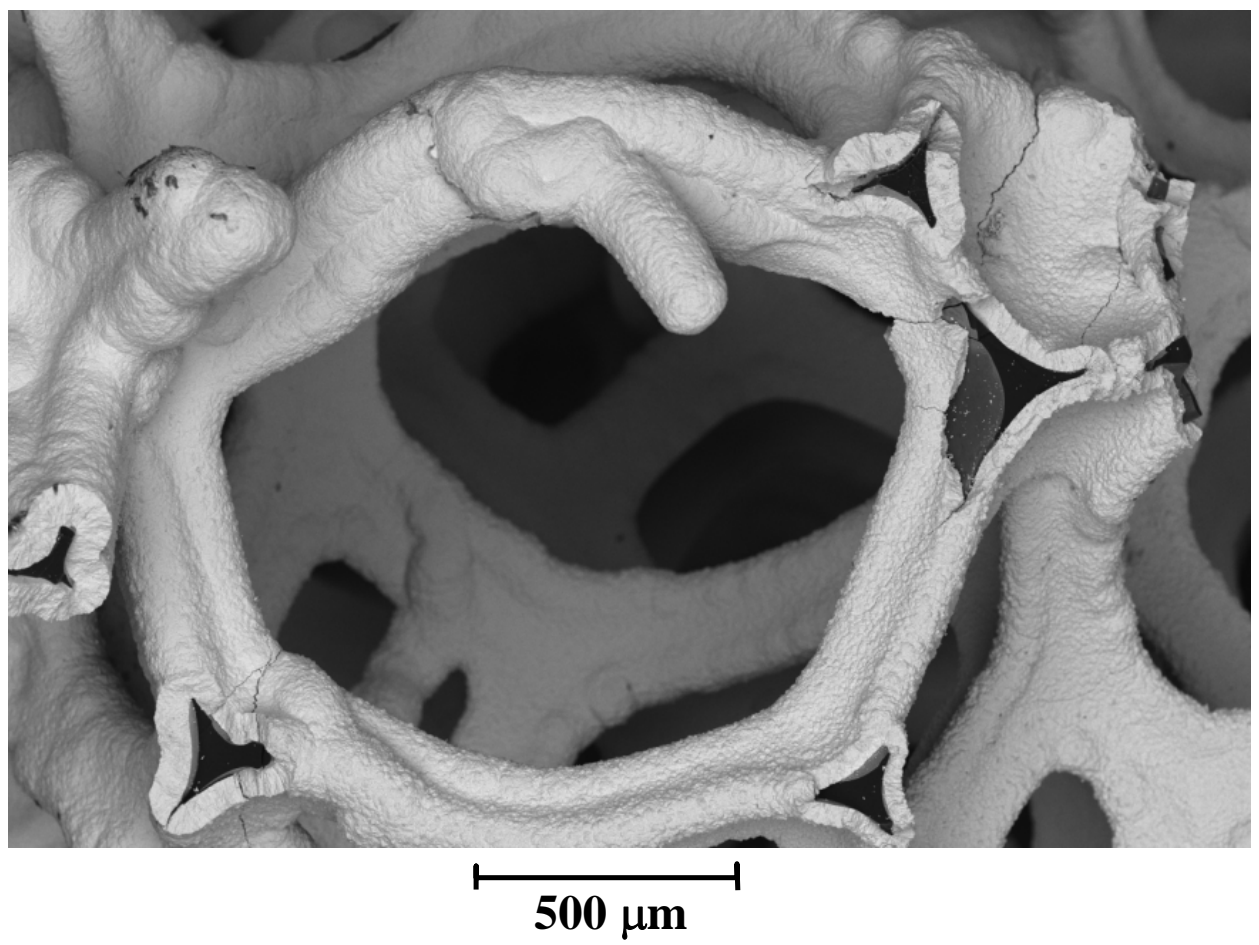

Figure 2a

4

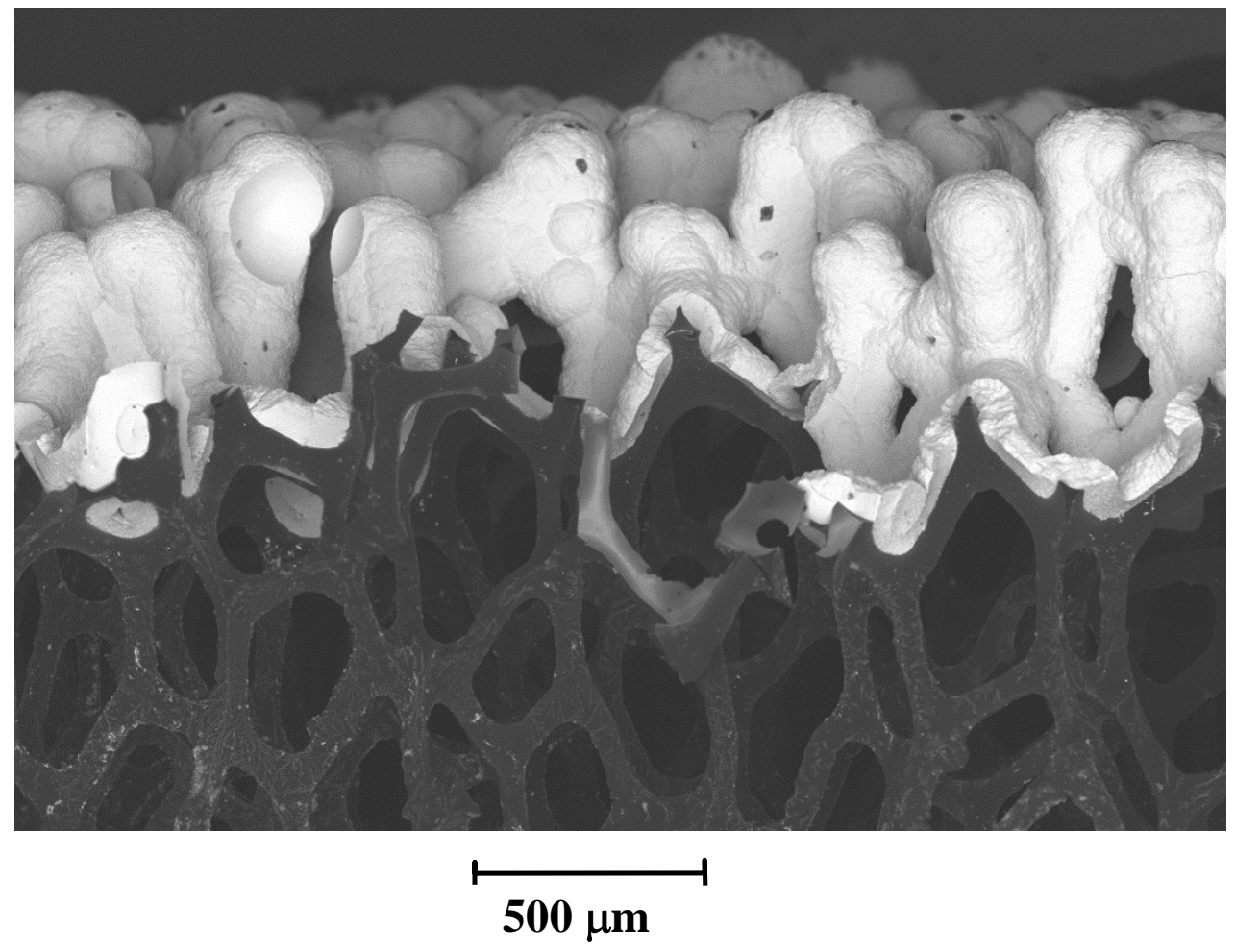

Figure 2b 


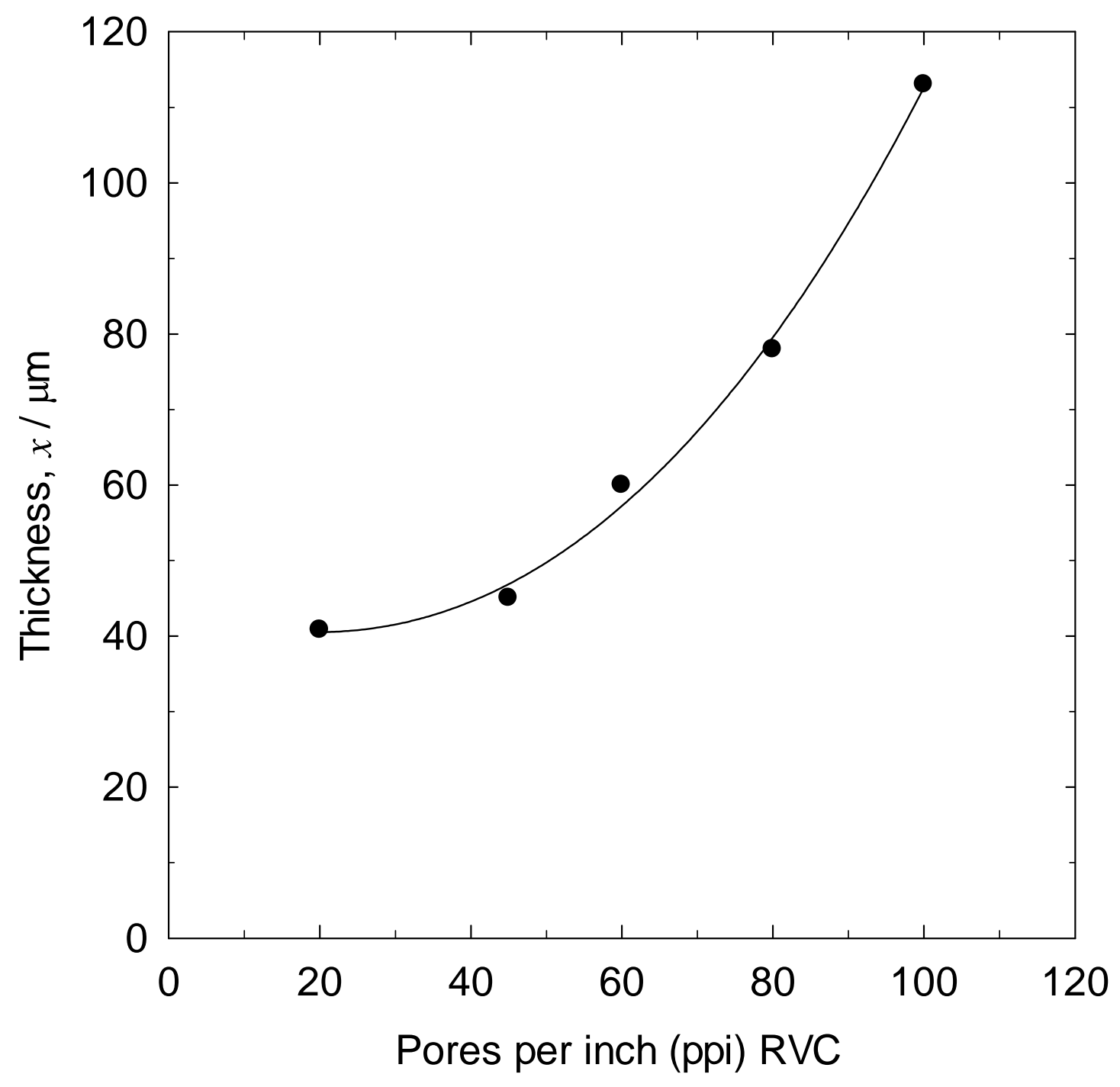

Figure 2c

5

6

7

8

9 


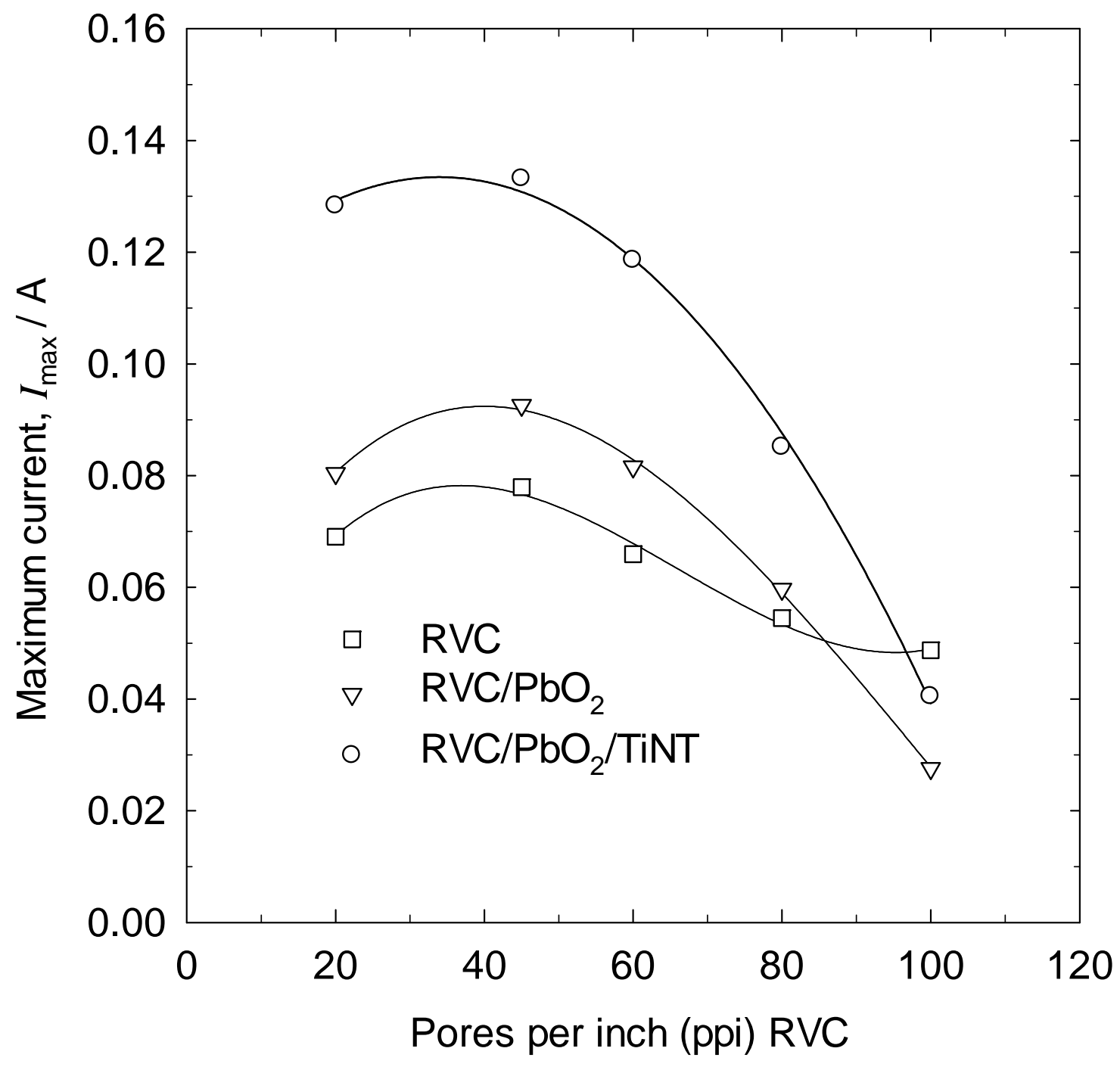

Figure 3

4 
2

3

4

5

6

7

8

9

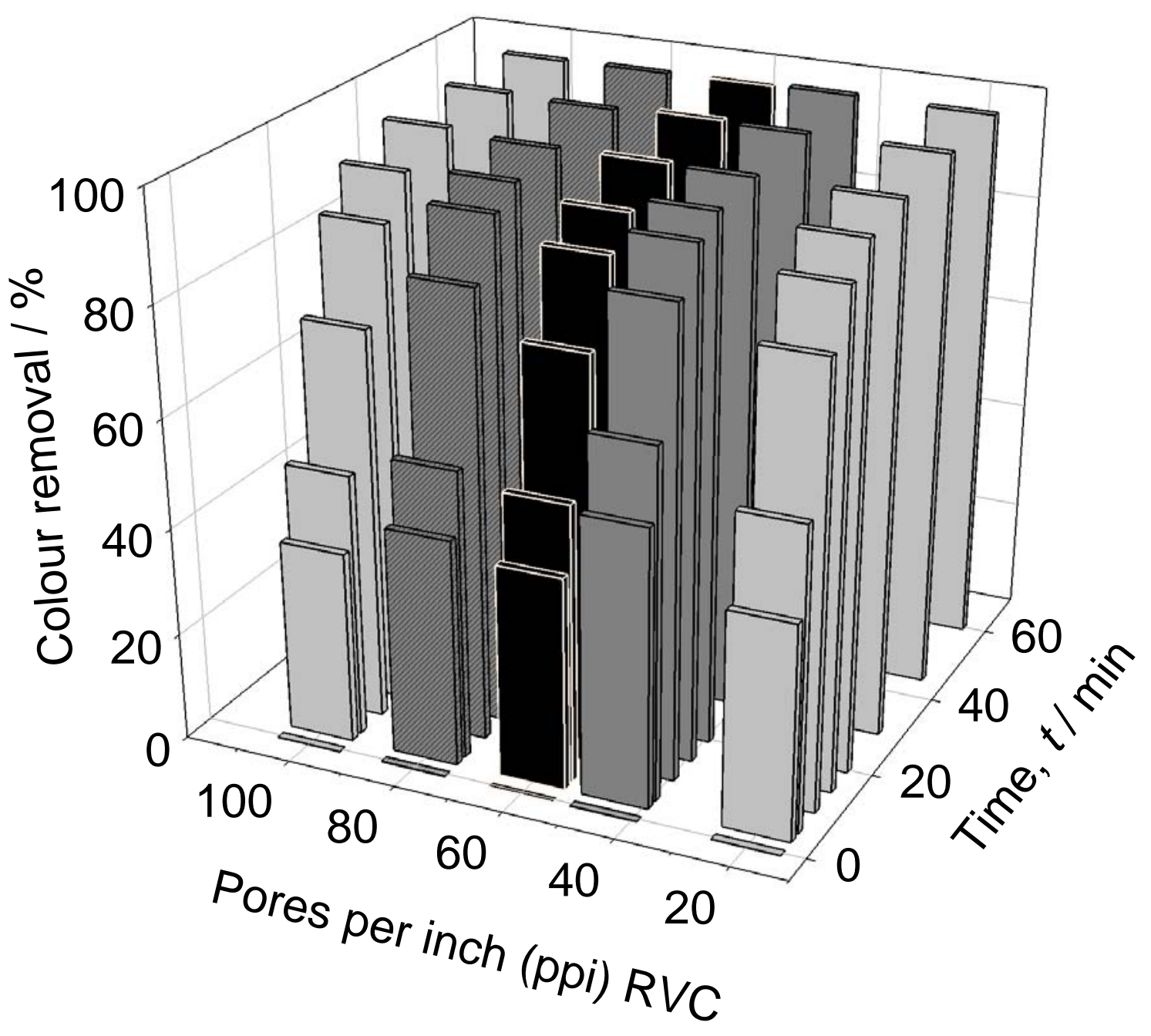

Figure 4a 


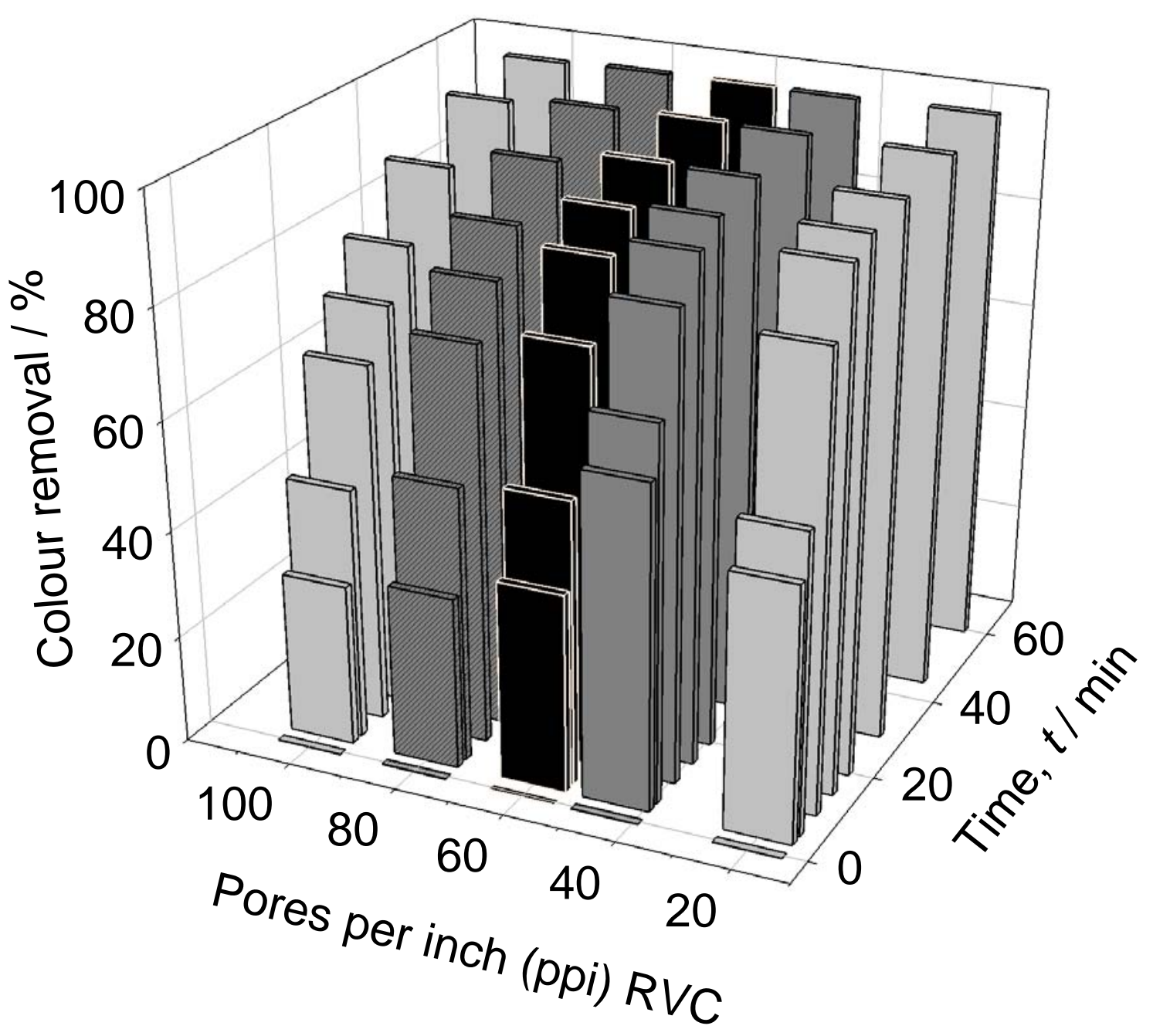

Figure 4b

5

6 


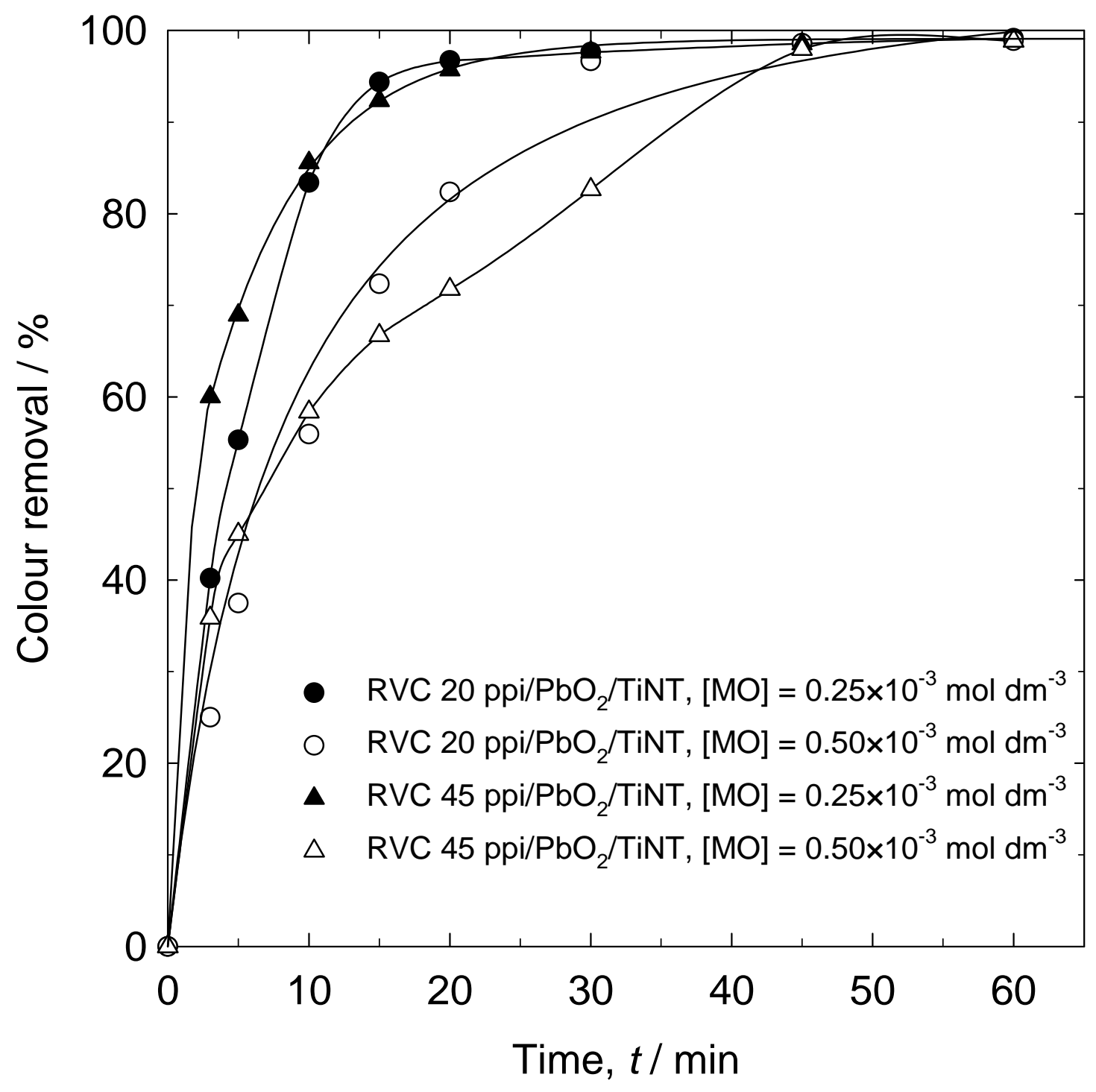

Figure 5a

5

6

7

8

9 


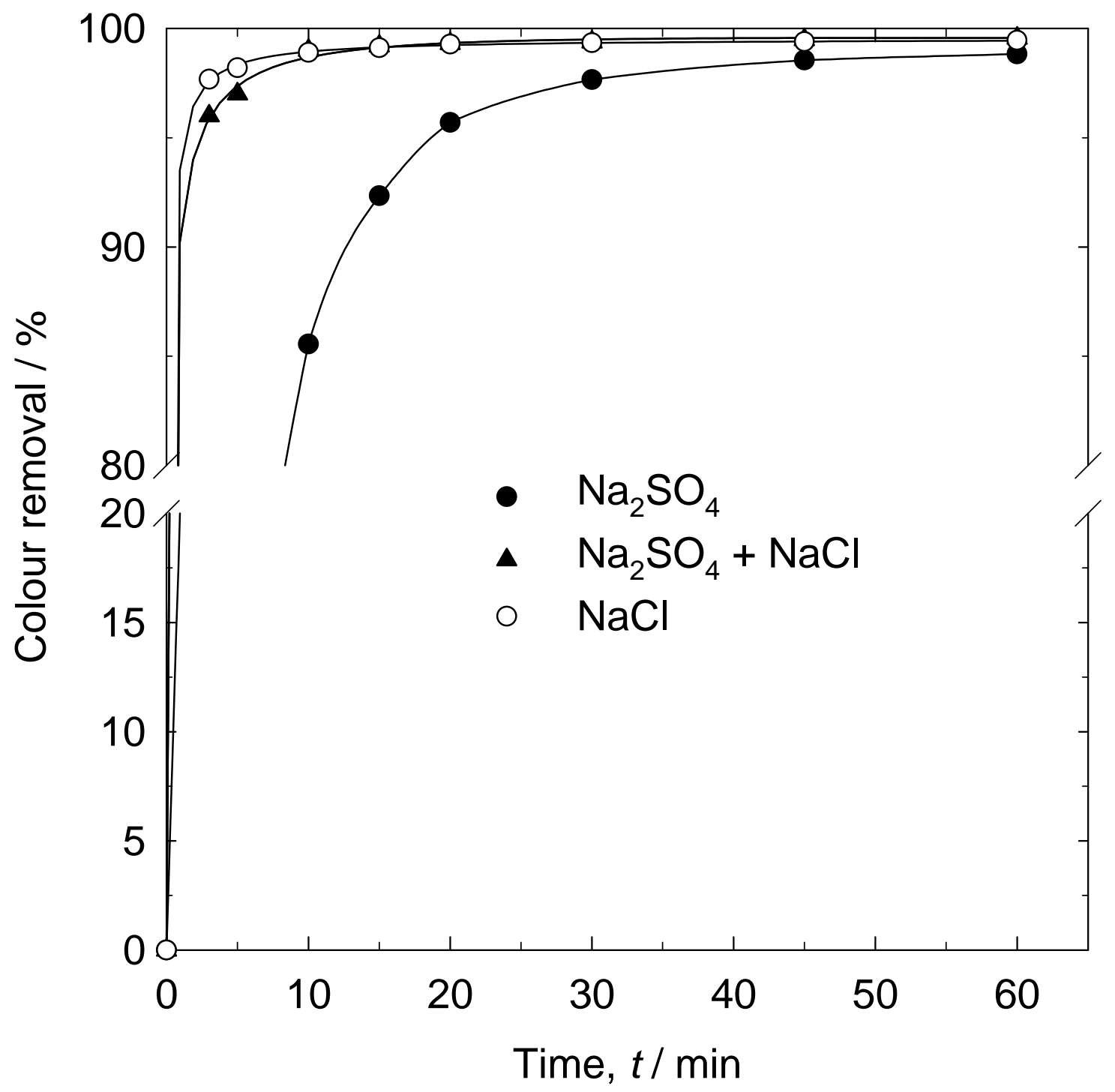

Figure 5b 